\title{
EL REY-PROFETA SALOMÓN Y LA IMAGEN DEL SOBERANO ISLÁMICO A PARTIR DE UNA PIEZA INÉDITA CORDOBESA
}

\author{
THE PROPHET KING SOLOMON AND THE IMAGE OF ISLAMIC \\ SOVEREIGN FROM AN UNPUBLISHED PIECE FROM CÓRDOBA
}

\author{
GUADALUPE GÓMEZ MUÑOZ
}

\begin{abstract}
Resumen: Damos a conocer una pieza inédita cordobesa: una placa islámica realizada probablemente en marfil, decorada mediante incisión en ambas caras con epigrafía y una compleja iconografía referente a Salomón como prototipo de soberano perfecto, destinada a legitimar el Estado omeya como heredero directo del mismo y por tanto de Dios.

Palabras clave: Placa. Marfil. Iconografía. Salomón. Dinastía omeya.
\end{abstract}

\section{INTRODUCCIÓN}

La pieza que analizamos en este artículo es una placa, al parecer de marfil, ${ }^{1}$ conservada en el Museo Arqueológico y Etnológico de Córdoba $\left(n^{\circ} 33.233\right)^{2}$. Está realizada en una sola pieza -actualmente incompleta fragmentada en dos- con forma de arco de medio punto peraltado, es decir, semicircular en la parte superior y recta en la inferior. Sus dimensiones son $8 ' 3 \mathrm{~cm}$ alto por 7' $8 \mathrm{~cm}$ de ancho, y entre los 7 y los $9 \mathrm{~mm}$ de grosor.

* Agradecemos a Fátima Gómez Muñoz la traducción del resumen y palabras clave al inglés.

1. La naturaleza de su material no es segura, ya que no se han practicado ningún tipo de análisis para determinarlo. Su adscripción como marfil se debe sólo a la observación visual y a las propias dimensiones, que consideramos excesivas para un soporte óseo

2. Acerca de su contexto poco podemos decir, ya que el origen de su aparición es fruto de un hallazgo casual en un vacie de vertidos de tierras procedentes de la Avda. del Aeropuerto de Córdoba.

\begin{abstract}
We expound an unpublished Cordova's object: an islamic plaque probably made in ivory, engraved in both sides with epigraphy and a complex iconography concerning to Solomon as the prototype of perfect sovereign, destinated to legitimate the Umayyad State as the direct heir of the same and therefore of God.

Key words: Plaque. Ivory. Iconography. Solomon. Umayyad dinasty.
\end{abstract}

En ambas caras se encuentra decorada con motivos grabados, aunque la profundidad de la incisión es muy superficial, seguramente agravada por el deterioro.

Presenta tres orificios, uno de ellos incompleto, además de suponerse una cuarta perforación. Estos orificios fueron realizados sin tener en cuenta la decoración de la placa, dispuestos interrumpiendo la misma, lo que nos hace pensar que fueron practicados con posterioridad a la decoración.

Por todas estas características, la funcionalidad de esta pieza pensamos que sería la de formar parte de un bote, correspondiendo a la tapa del mismo, con decoración al exterior e interior. De ahí la disposición de los orificios para albergar los remaches de los herrajes que unirían esta tapa al resto del bote.

Como ya hemos mencionado, ambas superficies presentan unos motivos grabados (láms. I y II). Una de las singularidades de esta placa radica en este hecho, ya que no conocemos trabajos en marfil o hueso que 


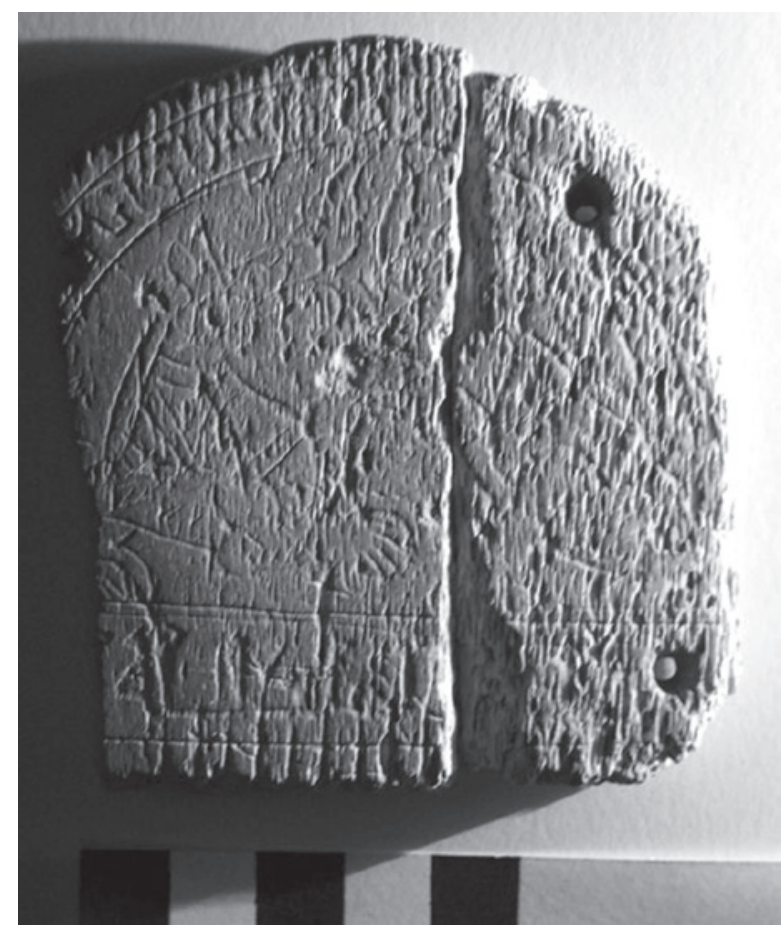

Lámina I. Placa cordobesa. Fotografía de la denominada cara 1 (Fuente: la autora).

presenten tal técnica, siendo éstos tallados en relieve, calados o pintados.

Se puede suponer que el dibujo se acentuara con policromía, ya que las arquetas y botes hispanomusulmanes que conocemos estaban pintados originalmente con vivos colores.

\section{LAS ARQUETAS Y BOTES DE MARFIL HISPANOMUSULMANES}

Los trabajos sobre marfil, realizados para la fabricación de arquetas y botes, se conocen en al-Andalus desde mediados del siglo $\mathrm{X}$, a partir del reinado de Abd al-Rahman III, con las obras procedentes del taller palatino de Madinat al-Zahra. De este taller conocemos dos artesanos: el denominado "de Zamora" por el bote que procede de esa catedral y que hoy día se conserva en el Museo Arqueológico Nacional; y el maestro Jalaf con el bote de la Sociedad Hispánica de Nueva York y la cajita de la iglesia de Fitero.

La técnica decorativa de estas primeras piezas consiste en la talla total de su superficie formando elaboradas y profusas composiciones a base de motivos florales y figurados, animales y humanos.

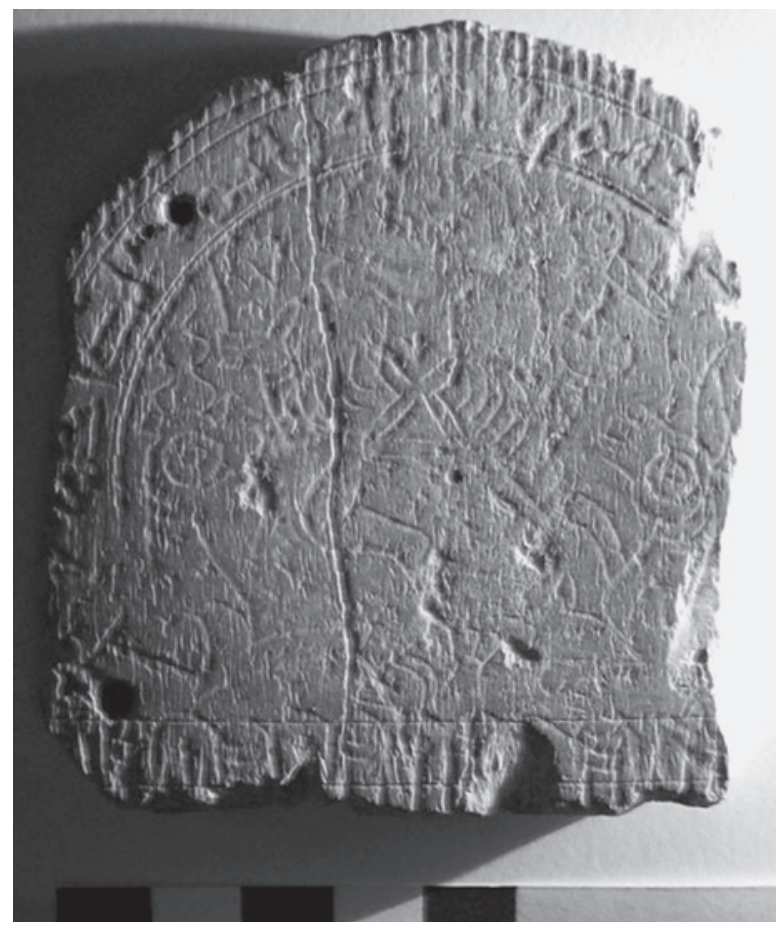

Lámina II. Placa cordobesa. Fotografía de la denominada cara 2 (Fuente: la autora).

Algunos autores diferencian otro taller en la ciudad de Córdoba, con una producción menos refinada y destinado a abastecer un mercado ajeno al ámbito de la corte, como propietarios de alto nivel económico o social (Beckwith 1960).

Con posterioridad, ya bajo el mandato de Almanzor, se supone la existencia de otro taller en Madinat al-Zahira, seguramente la continuación del taller califal, representado por la arqueta de Leyre, fechada en el año 1005, y el bote de Braga dedicado al hijo de Almanzor, Abd al-Malik, y firmado por el artesano Faray y sus discípulos. Estas obras presentan una técnica y un repertorio muy próximos a las del taller de Madinat al-Zahra, con escenas de la corte y animales asociados a la simbología real.

Tras la desaparición del califato, con los reinos de Taifas, los artesanos se establecen en las diversas cortes, limitándose a reproducir unos motivos seriados carentes de originalidad o innovación en sus decoraciones.

La estructura de las arquetas también pierde calidad, ya que se componen mediante múltiples placas de marfil que recubren un alma de madera.

Destaca en este periodo el Taller de Cuenca, con la caja de Silos fechada en 1026 y realizada por $\mathrm{Mu}-$ hammad ibn Zayyan, y la caja de Palencia de Abd 
al-Rahman ibn Zayyan de 1049 destinada a Ismail, hijo de al-Mamun, rey de Toledo.

A partir de los siglos XII y XIII desconocemos la ubicación de los talleres de eboraria andalusíes, ya que las obras de este periodo se destinan al comercio de lujo y son anónimas, presentando tan solo dedicatorias o eulogias impersonales. La decoración se atiene a la repetición de motivos de los periodos anteriores pero faltos de su fuerza expresiva.

En este último periodo se suma el importante comercio surgido en el Mediterráneo con las producciones de Sicilia. Con esta situación no sabemos diferenciar si las obras conservadas en al-Andalus de este momento son producciones autóctonas o fruto del comercio exterior.

Igualmente ocurre con una serie de botes cilíndricos con decoración de motivos geométricos calados, fechados a fines del siglo XIII y en el siglo XIV, siendo consideradas por algunos autores como obras nazaríes, aunque otros le establecen un origen en el Egipto mameluco a partir del bote de la colección Rothschild dedicado al sultán Salih. Una de estas obras se conserva en la catedral de Zaragoza.

De este modo, siguiendo a José Ferrandis, los marfiles de este último periodo se pueden agrupar en cuatro series atendiendo al modo de realización de su decoración: marfiles con figuras talladas; marfiles calados; marfiles pintados (Sicilianos y andalusíes); y los marfiles de los talleres reales granadinos (Ferrandis 1940).

\section{LA PIEZA CORDOBESA. DESCRIPCIÓN DE SUS MOTIVOS E ICONOGRAFÍA}

Como ya hemos mencionado, la técnica con la que está realizada la placa cordobesa resulta del todo novedosa respecto a las producciones de marfil que conocemos. Ambas caras se encuentran decoradas por medio de trazos grabados o incisos. Los motivos están realizados con líneas muy simples, que se atienen a dibujar las figuras y definir algún elemento característico dentro de las mismas. Igualmente, ambas superficies albergan leyendas realizadas en cúfico simple ${ }^{3}$.

\section{Cara 1 (fig. 1)}

La escena figurada está enmarcada en su parte superior por un semicírculo y en la inferior por una línea recta, adaptándose a la forma del soporte en que se

3. Agradecemos a Juan A. Souto las precisiones sobre la transcripción de las inscripciones.

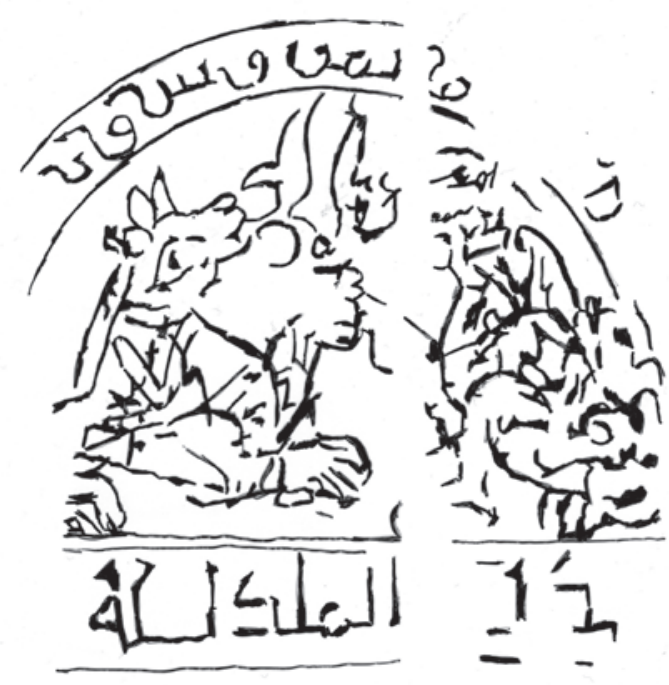

Figura 1. Placa cordobesa. Dibujo de la denominada cara 1 (Fuente: la autora).

dispone. Al exterior de este encuadre y dentro de una banda se encuentran dos inscripciones. La situada en la zona superior presenta una leyenda incompleta pero en la que se puede leer "...yumn wa surur...” o “...prosperidad y gozo...”. Esta inscripción está escrita en cúfico simple con una tendencia a alargar y curvar la terminación de los trazos de las letras "nun", "waw" y "ra". Como vemos se trata de una inscripción con carácter de eulogia para su poseedor.

Bajo la escena hay otra inscripción -también incompleta- con la leyenda "al-mulk lillahi" o "el poder/ el reino (es) para Dios", aunque se puede leer precediéndola las letras "kaf" y "lam" por lo que puede tratarse de la misma frase repetida. Esta inscripción está realizada en cúfico simple al igual que la anterior, aunque el desarrollo de las letras es más geométrico o anguloso y tienen un tamaño mayor, debido quizás al significado religioso de la frase.

El motivo que se representa dentro de este encuadre epigráfico es de carácter fantástico. Se trata de dos seres imaginarios enfrentados en un eje de simetría. Estos seres no son idénticos en su forma pero sí en su disposición ya que ambos se encuentran recostados alzando la cabeza y una de sus patas delanteras, las cuales se tocan entre sí, y de sus bocas nacen sendas palmetas.

Llama la atención el hecho de que no sean similares entre sí y no haya un eje central físico que los separe, puesto que en el resto de marfiles y otros objetos con este tipo de motivo, los animales y seres fantásticos 
se suelen presentar en composiciones formadas por un eje central vegetal y un animal a cada lado, de forma enfrentada, siendo ambos idénticos tanto en su postura como características formales.

Dentro de los motivos que se desarrollan en la eboraria califal son frecuentes este tipo de escenas o composiciones con animales, reales o fantásticos, los cuales tienen su origen en la iconografía oriental, encontrándose en productos de lujo persas y sasánidas como tejidos, orfebrería y metalistería (Ferrandis 1935: 22).

\section{Cara 2 (fig. 2)}

La escena se sitúa, al igual que ocurre en la cara anterior, adaptándose a la forma del soporte: enmarcada en su parte superior por un semicírculo y en la inferior por una línea recta. En la banda superior se halla la inscripción "... [bara]ka min Allah wa yumn li-sahibi-hi" o "...bendición de Dios y prosperidad para su dueño", aunque incompleta en su inicio.

En el centro de la composición figurada se sitúa una figura masculina sedente. Este personaje está sentado con las rodillas flexionadas sin ningún asiento donde apoyarse, por lo que parece estar flotando en el aire. Ambos brazos los mantiene levantados, sosteniendo con su mano derecha un vaso o copa y con su izquierda un pájaro. Presenta el peinado a modo de una melena,

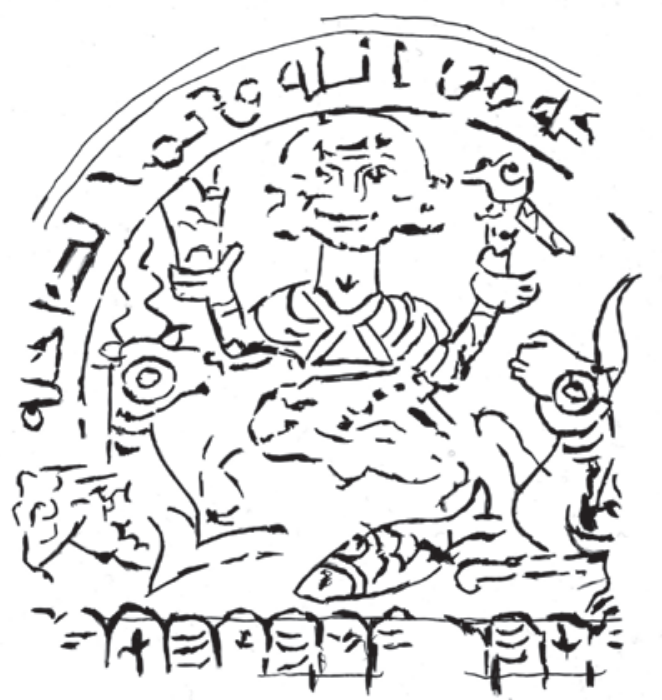

Figura 2. Placa cordobesa. Dibujo de la denominada cara 2 (Fuente: la autora). abultado en sus puntas y con flequillo. Este tipo de peinado lo encontramos en otros personajes representados en el bote Davillier de hacia el 970, conservado en el Museo del Louvre ( $\left.n^{\circ} 2774\right)$. La vestimenta, con manga hasta las muñecas, se realiza a base de pliegues muy marcados y en el pecho se cruzan dos bandas en aspa. Esta tendencia a marcar los pliegues del ropaje la encontramos en las figuras de los músicos del capitel del mismo nombre expuesto en el Museo Arqueológico y Etnológico de Córdoba ( $\left.\mathrm{n}^{\mathrm{o}} \mathrm{D} / 133\right)$. Un elemento que también destaca en esta figura es el que se sitúa en el centro de su cuello, del cual hablaré más adelante.

Alrededor de este personaje masculino y en un nivel inferior se encuentran tres animales propios de los medios terrestre y acuático. Flanqueándolo se sitúan dos mamíferos sedentes que se dirigen hacia él con su mirada y una de sus patas delanteras en claro sentido de sumisión o admiración.

El mamífero situado a la derecha del humano se puede identificar como un antílope, en concreto un addax, animal que se caracteriza por sus cuernos largos y divergentes con un desarrollo en espiral ${ }^{4}$.

La adscripción del otro mamífero a una especie no es tan segura, ya que sólo son destacables sus grandes orejas y labios prominentes, pudiéndose tratar de un onagro o asno salvaje.

El tercer animal es un pez, situado bajo el personaje humano, representado de forma genérica acentuándose sus escamas.

Situada como límite inferior de toda esta escena se desarrolla una franja compuesta por series de tres líneas horizontales paralelas enmarcadas que se alternan con elementos vegetales estilizados también enmarcados.

Además de este análisis descriptivo de la cara 2 hay que hacer otro de carácter iconográfico centrándonos en su posible significado a través de algunos de los elementos que se representan:

Siguiendo a Juan Zozaya, el vaso o copa -llamado "onom"- que sostiene la figura sedente en su mano derecha representa el poder del personaje que lo porta (Zozaya 2002: 124).

El pájaro, que sostiene en su izquierda, simboliza en el Islam, y en numerosas culturas, el alma humana (Schimmel 2002: 324).

Dentro del cuello del personaje hay un elemento muy esquematizado que identificamos como una flor de loto en su proceso de floración, de ahí que presente tres pétalos. En relación con este elemento se encuentra el friso de la zona inferior, el cual puede tratarse

4. Se trata de una especie en extinción que ocupaba hasta hace unas décadas todo el norte de África, Palestina y Arabia. 
de la representación de capullos de loto en su medio acuático representado por estas series de líneas anteriormente descritas que simulan ondas de agua. La flor de loto, desde época protohistórica ha representado en Oriente la eternidad o vida eterna (Turina 1981: 455) además de ser un símbolo de pureza, por lo que en este caso puede estar asociada a un personaje al que se le desee o esté en relación con esta característica divina. Además se puede apuntar, siguiendo de nuevo a Zozaya, el hecho de que el capullo de loto se identifica con la palabra paz por ser en árabe palabras homófonas o que presentan casi el mismo sonido en su pronunciación (Zozaya 2002: 136).

\section{Paralelos}

A partir de todo este análisis pensamos que puede tratarse de la representación del poder del soberano revestido de un carácter sagrado. Para argumentar esta hipótesis mostraremos otras representaciones de príncipes entronizados de sobra conocidas.

En primer lugar, el fresco del palacio jordano de Qusayr 'Amra, fechado en torno al 714, durante el reinado de al-Walid I. En él se representa en el centro de la composición, pero a un nivel superior, la figura de un soberano entronizado y a los lados de éste dos sirvientes. Bajo estas tres figuras se nos muestra el mar con la presencia de un barco y un gran pez, hoy día muy perdido pero visible en el dibujo que hiciera el pintor Millich a finales del siglo XIX (lám. III). Enmarcando toda la escena hay una serie de pájaros de entre los que destaca el que se sitúa sobre la cabeza del príncipe, identificado por Christian Ewert (q.e.p.d.) como símbolo del poder de este personaje. Además, según señala este mismo autor, a partir de esta escena "el príncipe entre mar y cielo se instala como motivo fijo en el arte islámico" (Ewert 1991: 127).

Como vemos, la placa cordobesa tiene en común con este fresco varios elementos: un personaje principal situado en una zona central destacada; el mar o mundo acuático a sus pies y la presencia de un ave relacionada con esta figura.

El siguiente motivo que hace alusión a la imagen del príncipe entronizado es un cuenco de loza dorada del siglo X procedente de Irak (lám. IV). En él se nos muestra con un dibujo muy simple y esquemático un personaje sedente, con las piernas flexionadas, que no se apoya en ningún asiento, dando la sensación de estar flotando en el aire. Además sostiene en su mano derecha una copa y en la izquierda un ramillete, identificado por Ewert como un racimo de uvas en alusión quizás al

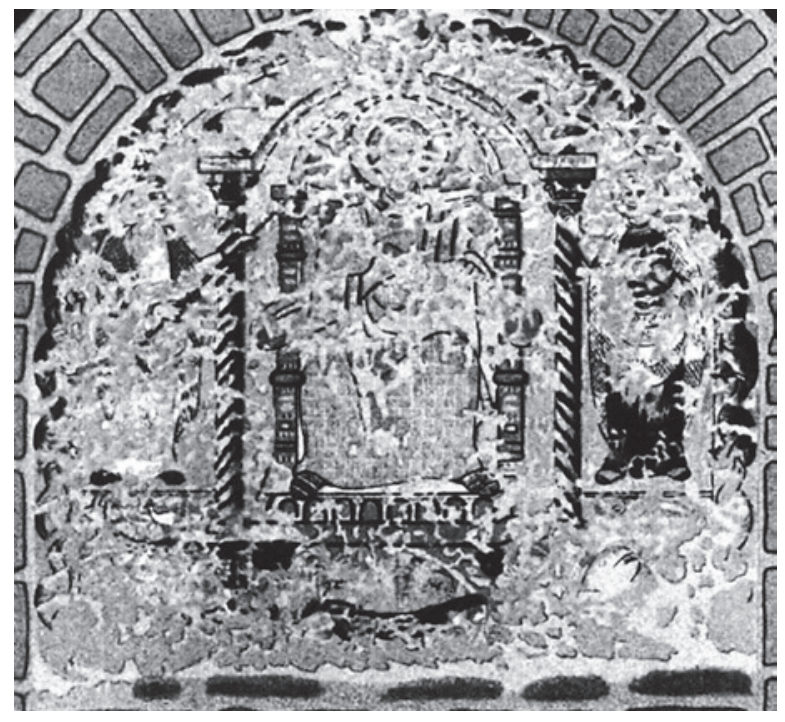

Lámina III. Fresco del palacio de Qusayr 'Amra, Jordania. Hacia 714. Dibujo del pintor Millich. (Fuente: Ewert 1991).

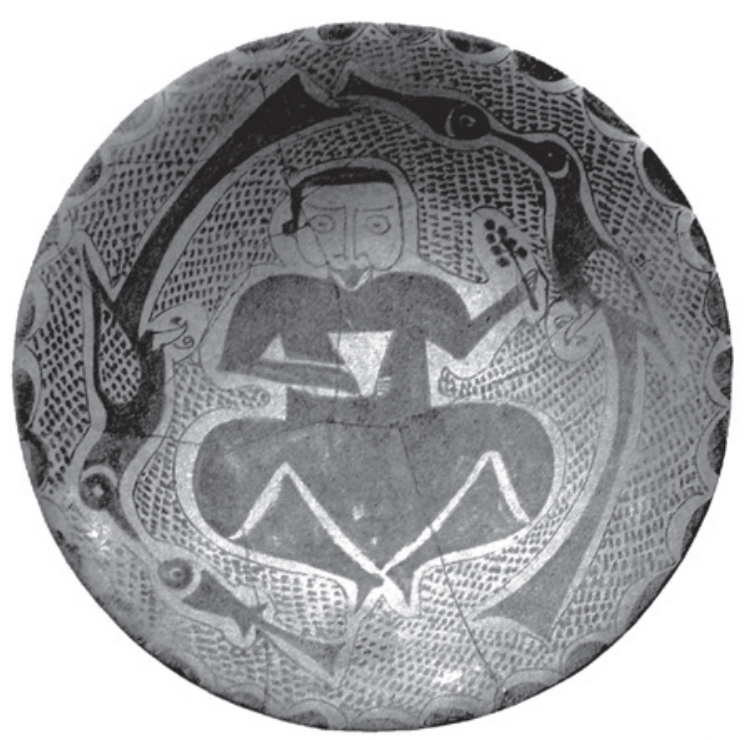

Lámina IV. Cuenco loza dorada. Irak. Siglo X. (Fuente: AA.VV. 1992).

Paraíso (Ewert 1991: 127). Enmarcándolo hay un friso compuesto de pájaros y peces.

De nuevo encontramos elementos en común: la figura sedente sentada en el aire y que sostiene una copa, así como la presencia de pájaros y peces.

Otras imágenes de iconografía real las encontramos en al-Ándalus, como la representación del califa Mu'awiya, fundador de la dinastía omeya, en el tejido 


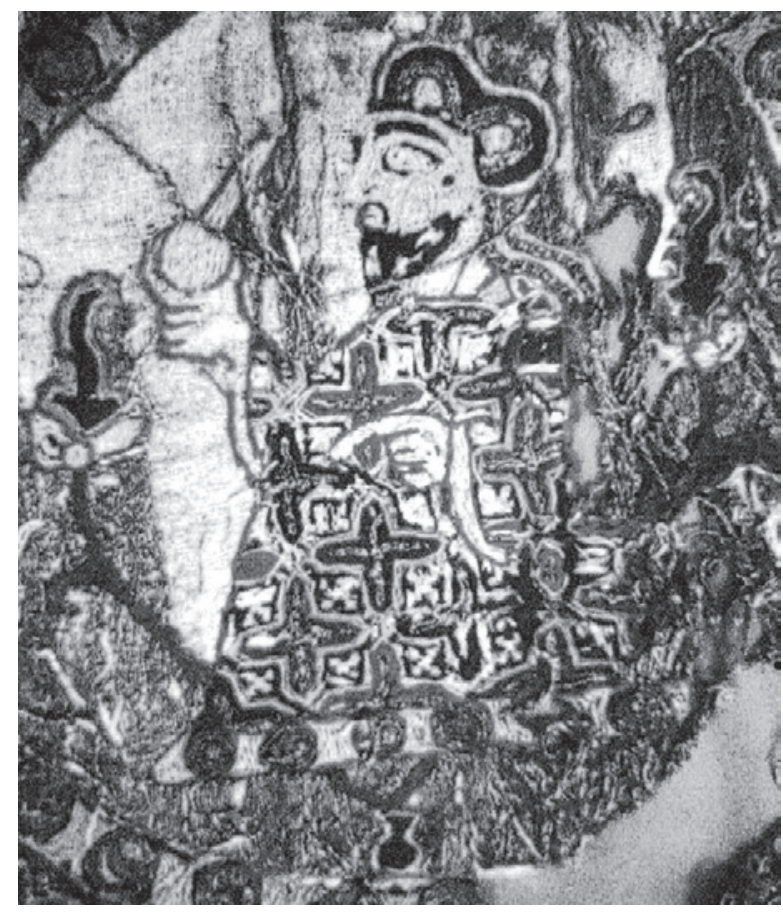

Lámina V. Representación de Mu'awiya sobre tejido. Colegiata de Oña, Burgos. Época califal. (Fuente: Zozaya 2002).

califal de la colegiata de Oña (Burgos) (lám. V). Éste se encuentra sentado sobre un trono y sosteniendo una botella con su mano derecha. Bajo él hay otra jarra o botella de la que brotan dos ramas que acaban, en lo que identifica Zozaya como capullos de loto (Zozaya 2002: 124).

Los símbolos en común de esta representación con nuestra pieza son la postura sedente del personaje, el recipiente sostenido en la mano derecha y los capullos de loto.

Por último, señalar una de las escenas de la arqueta de Leyre, perteneciente a época amirí y dedicada a 'Abd al-Malik, hijo de Almanzor (lám. VI). Centrándonos en uno de los medallones que la decoran en su frente se observa en el centro de la composición un personaje sentado con las piernas flexionadas sosteniendo un jarro, en este caso, en su mano izquierda. A sus lados se encuentran dos sirvientes representados con un tamaño menor que la figura central por claro motivo de escala jerárquica. Éste personaje se ha identificado con 'Abd alMalik por el anillo que porta en su mano izquierda.

Los puntos afines a nuestra pieza son la postura del personaje central, y el hecho de estar sosteniendo un recipiente.

Por lo tanto, si comparamos la placa cordobesa con el conjunto de las imágenes expuestas podemos

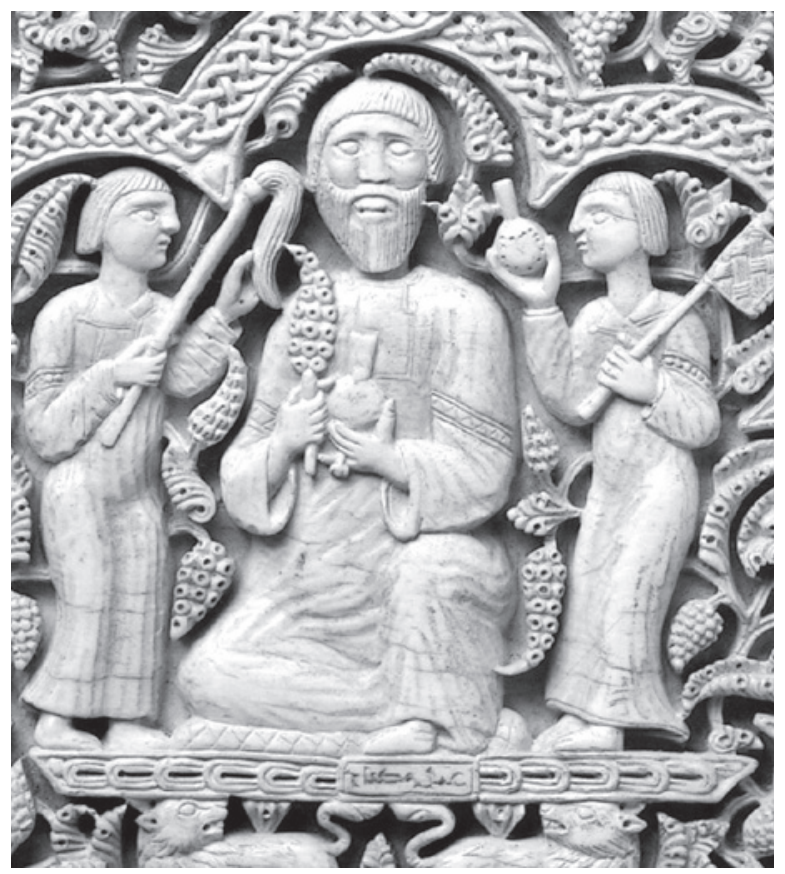

Lámina VI. Escena de uno de los medallones de la arqueta de Leyre. Museo de Navarra, Pamplona. 1004-5. (Fuente: AA.VV. 1992).

observar que la única diferencia que presenta respecto a ellas son los seres que flanquean la figura central, los cuales no son humanos, sino animales.

De este modo, estamos ante un personaje al que los animales salvajes hacen la función de sirvientes o cuanto menos parecen obedecerle en un gesto de sumisión plasmado mediante la dirección de sus miradas y patas delanteras. En este aspecto, es de destacar una máxima de la mística islámica o sufismo que dice que "a quien obedece totalmente a Dios, le obedece obligatoriamente toda la Creación" (Schimmel 2002: 225), siendo un ejemplo de ésta la representación del santo legendario iraní Majnun (lám. VII). Esta relación entre animales y hombre se debe a que "todas las criaturas alaban a Dios en su propio lenguaje y quien ha purificado su alma puede comprender su alabanza y unirse a ellas" (Schimmel 2002: 231).

\section{SALOMÓN: EL REY-PROFETA}

Finalmente haremos unas consideraciones sobre el concepto de la dinastía omeya y de una figura importante para el Islam: el rey-profeta Salomón.

Desde la aparición de la dinastía omeya en Oriente, sus califas se conciben como los sucesores de Mahoma 


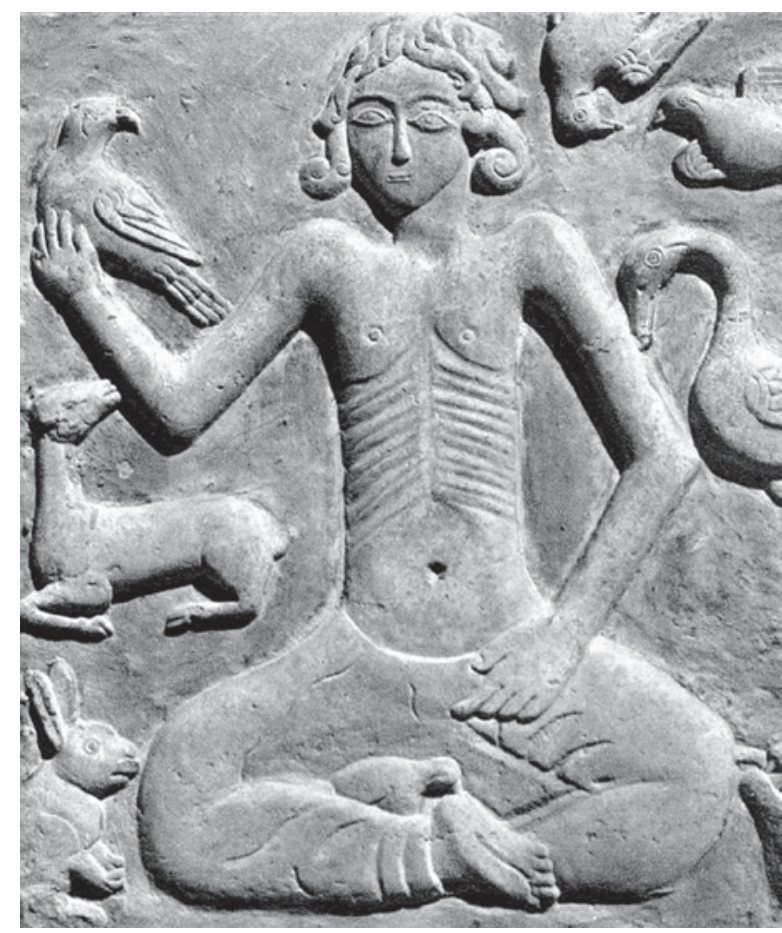

Lámina VII. Majnun en el desierto, en medio de los animales salvajes. Shiraz, Irán. Segunda mitad s. XVIII. (Fuente: Godard 1969).

así como de los profetas y monarcas anteriores a éste, entre los que se encuentran David y Salomón, ambos considerados como el prototipo del soberano perfecto. De este modo la dinastía omeya asume un carácter divino por influencia del imperio bizantino y del mundo persa, siendo los soberanos guiados en su gobierno por inspiración divina (Crone y Hinds 1990: 114-115).

Según Oleg Grabar: "desde el momento de la creación del imperio musulmán, fue creciendo una conciencia salomónica, $\mathrm{y}$, más pronto o más tarde, lenta o rápidamente, para todos los temas, mitos e ideas relativos a la vida del príncipe y a su entorno, se llegó a establecer una asociación automática con Salomón" (Grabar 2001: 151).

Salomón es, en la tradición oriental, el sabio poseedor de prudencia política, cualidades que proceden directamente de Dios, ya que es el elegido como representante suyo en la tierra. Además de destacar por su faceta de perfecto conocedor de la Naturaleza (Alonso 2002: 70-73).

Por todas estas virtudes, en las representaciones islámicas del rey-profeta se le suele mostrar sentado en su trono y rodeado de otros personajes, así como de animales en gesto de sumisión y admiración (lám. VIII).

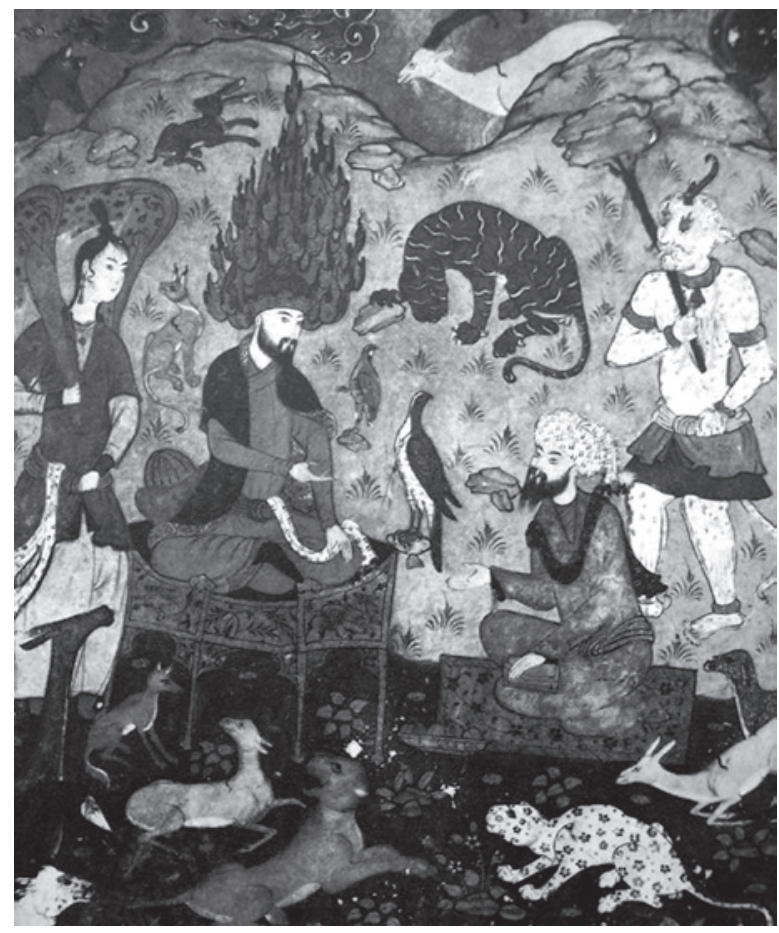

Lámina VIII. ISHAQ NISHAPURI. Historia de los Profetas. "Salomón en un trono". Ispahán, Irán. Hacia 1590-1600.

(Fuente: Papadopoulo 1977).

\section{CONCLUSIONES}

A lo largo de los párrafos anteriores hemos analizado la pieza en cuanto a sus motivos y su posible significado. A partir de este análisis se pueden extraer varias conclusiones.

La primera de ellas es su posible adscripción al taller califal -que algunos autores defienden- ubicado en la ciudad de Córdoba con producciones menos refinadas y con un mercado ajeno a la corte, por su eulogia impersonal que la clasifica como una pieza de mercado y los elementos que la datan en época califal avanzada, como el tipo de escritura-realizada en cúfico simple, el cual se desarrolla a partir del año 965, en época de alHakam II-, y las características formales del personaje central -en concreto el peinado y la vestimenta- que como hemos visto anteriormente presenta paralelos en objetos de esta cronología.

Otro aspecto importante es su iconografía y el origen de sus motivos. A pesar de poder pertenecer a este taller, tampoco es descartable que pueda tratarse de un objeto importado, ya que la técnica con la que está realizado es diferente a los marfiles andalusíes conocidos, y sobretodo su iconografía de claro origen oriental, en 
la que se representa una especie animal desconocida en Occidente y oriunda del Norte de África y Oriente Próximo como es el addax.

Creemos haber llegado a la conclusión que el motivo representado en la que hemos denominado aleatoriamente como cara 2 es la representación de Salomón, profeta y modelo de soberano a seguir por los califas omeyas.

La placa de Córdoba respondería, pues, a una producción diferente de los marfiles califales conocidos debido a dos razones: el carácter impersonal de sus inscripciones y la técnica de su decoración, menos elaborada y por lo tanto menos costosa. De este modo esta producción estaría dedicada a una clientela anónima pero de alto poder económico, la cual con la compra de este tipo de productos de lujo intentaría emular a la corte.

Sin embargo la corte también entraría en juego con la incorporación de motivos simbólicos que legitiman el Estado omeya, en este caso con la representación de Salomón como precedente de los califas omeyas -y por extensión cordobeses - y el lema ya conocido de "almulk lillahi” o "el poder es para Dios". Por lo tanto la cara 2 nos muestra la representación de Salomón como el modelo de soberano perfecto.

En resumidas cuentas, se trata de un objeto destinado a legitimar el Estado omeya como heredero directo de Salomón y por tanto de Dios.

\section{BIBLIOGRAFÍA}

AA.VV. (1992): Al-Andalus: las artes islámicas en España. Madrid.

AA.VV. (2000): Las Andalucías de Damasco a Córdoba. París.

ALONSO LÓPEZ, J. (2002): Salomón. Entre la realidad y el mito. Madrid.

BECKWITH, J. (1960): Caskets from Cordova. Londres.
CRONE, P. y HINDS, M. (1990): God's Caliph. Religious authority in the first centuries of Islam. Cambridge.

EWERT, C. (1991): "Precursores de Madinat al-Zahra. Los Palacios omeyas y abbasíes de oriente y su ceremonial aúlico", Cuadernos de Madinat al-Zahra 3: 123-163.

FERRANDIS, J. (1935): Marfiles árabes de Occidente. 1. Marfiles hispanoárabes (siglos X y XI). Madrid.

- (1940): Marfiles árabes de Occidente. 2. Marfiles árabes de Occidente (siglos XI-XV). Madrid.

GALÁN Y GALINDO, A. (2005): Marfiles medievales del Islam. 2 tomos. Córdoba

GARCÍA FONT, J. (1995): La mística sufí de los poeta persas. Barcelona.

GODARD, A. (1969): El arte del Irán. Barcelona.

GRABAR, O. (2001): La Alhambra: iconografía, formas y valores. Madrid.

LEGUINA, E. de (1912): Arquetas Hispano - Árabes. Madrid.

MONTOYA TEJADA, B. y MONTOYA DÍAZ, B. (1979): Marfiles cordobeses. Córdoba.

NIZÂMÎ (1991): La historia de Layla y Majnún. Trad. y notas de Jordi Quingles. Barcelona.

OCAÑA JIMÉNEZ, M. (1970): El cúfico hispano y su evolución. Cuadernos de Historia, Economía y Derecho Hispano-musulmán 1. Madrid.

PAPADOPOULO, A. (1977): El Islam y el Arte Musulmán. Barcelona.

PÉREZ HIGUERA, T. (1994): Objetos e imágenes de al-Andalus. Madrid.

SCHIMMEL, A. (2002): Las dimensiones místicas del Islam. Madrid.

TURINA GÓMEZ, A. (1981): “Algunas influencias orientales en la cerámica omeya andalusí”, II Coloquio Cerámica Medieval del Mediterráneo Occidental: 455-459. Toledo.

ZOZAYA, J. (2002): "Iconografía califal", en J.L. del Pino (coord.), Al-Andalus Omeya: 119-142. Córdoba.

Fecha de ENTRADA: 08-11-2007

FECHA DE ACEPTACIÓN: 25-09-2008 